\title{
Establishing a typology of open innovation strategies and their differential impacts on innovation success in an Asia-Pacific developed economy
}

\author{
Colin C. J. Cheng ${ }^{1} \cdot$ Eric C. Shiu ${ }^{2}$ (I)
}

Published online: 8 June 2019

(C) The Author(s) 2019

\begin{abstract}
Firms use open innovation strategy to explore external knowledge or exploit internal knowledge to benefit their product/service innovations, and thus enhance their innovation performance. However, a lack of relational mechanisms makes it more difficult for collaborative partners to share their knowledge assets. Existing literature lacks a clear explanation of how knowledge and relational mechanisms simultaneously function for innovation success. In response, this study attempts to answer: (1) Can archetypes of open innovation strategies be identified by knowledge and relational mechanisms simultaneously? And, (2) Do they differ in their ability to predict innovation success under the condition of innovation process characteristics? An exploratory study of 78 open innovation firms reflects four archetypes of open innovation strategies. A subsequent cross-industry survey of 248 open innovation firms in Taiwan reveals that the four archetypes of open innovation strategies result in varying degrees of innovation success, and innovation process characteristics positively moderate such associations.
\end{abstract}

Keywords Open innovation · Knowledge mechanism · Relational mechanism · Innovation process characteristics

Eric C. Shiu

e.c.shiu@bham.ac.uk

Colin C. J. Cheng

cjcheng@gm.ntpu.edu.tw

1 Department of Business Administration, National Taipei University, Taipei, Taiwan

2 Birmingham Business School, University of Birmingham, Birmingham, UK 
In developed economies ${ }^{1}$ such as Taiwan ${ }^{2}$ and South Korea, firms tend to keep research and development (R\&D) in-house but now they increasingly rely on searching for alternative approach to innovation, namely, open innovation, referring to a strategy that opens internal innovation processes and collaborates with external entities (West, Salter, Vanhaverbeke, \& Chesbrough, 2014). For example, the success of TSMC, the world's largest semiconductor contract manufacturer in Taiwan, is partially attributed to the establishment of an open innovation platform, in which suppliers/buyers are obligated to reciprocate in knowledge exchanges through which they share knowledge frequently and freely (Chesbrough, 2012). Because its knowledge bases offer opportunities for knowledge combination and integration, TSMC and its partners can enhance their innovation performance. This trend, especially in Asia Pacific markets such as Taiwan, results primarily from the difficulty that firms face in developing their R\&D and innovation knowledge (Liu, Chen, \& Wang, 2017).

Firms such as TSMC in Asia Pacific developed economies seem to emphasize on knowledge combination and integration for their open innovation strategy. However this study argues that relational mechanisms can also be powerful means for these Asia Pacific firms who strive to maximize open innovation performance (Bogers, Zobel, Afuah, Almirall, Brunswicker, \& Dahlander, 2017). Relational mechanisms reflect the values shared among partners concerning appropriate behavior that maintains or improves their relationship (Li, Poppo, \& Zhou, 2010). Firms must act purposefully to coordinate the flow of knowledge from partners' relationships in a way that does not leave it to chance (Pan et al., 2015). To do this, open innovation firms must bring together knowledge and relational mechanisms.

The empirical literature on open innovation points clearly to the importance of factors that relate to knowledge or relational mechanisms. Previous research shows that knowledge flows (Cassiman \& Valentini, 2016; Dahlander \& Gann, 2010), knowledge sharing (Ritala, Olander, Michailova, \& Husted, 2015; Van de Vrande, De Jong, Vanhaverbeke, \& De Rochemont, 2009), and knowledge integration (Lakemond, Bengtsson, Laursen, \& Tell, 2016; Van Burg, Berends, \& Van Raaij, 2014) influence open innovation performance. Strong inter-organizational relationships can help firms to accelerate their entrance into international markets (Eftekhari \& Bogers, 2015), leverage value in innovation networks (Sisodiya, Johnson, \& Grégoire, 2013), and be the main advantage over competitors (Gronum, Verreynne, \& Kastelle, 2012; Dahlander \& Frederiksen, 2012). However, prior studies on open innovation seem to focus on the single area of either knowledge or relational mechanism. Recently, Bogers et al., (2017) indicate that increasing relationship intensity can stimulate open innovation activities, and its contribution to innovation performance cannot be divorced from knowledge mechanisms inside the open innovation firm. Furthermore, it is highly unlikely that open innovation firms benefit similarly from these two mechanisms, because different open innovation firms are different in combining and configuring their knowledge and relational mechanisms (Saebi \& Foss, 2015). Thus, what is missing is a theoretical treatment and

\footnotetext{
${ }^{1}$ We distinguish new developed economies such as Taiwan and South Korea from traditional developed economies such as the USA and the UK in this paper. Further elaboration of this point can be found towards of this section.

${ }^{2}$ We use the criteria of economics fundamentals to assess Taiwan as a developed economy (Investopedia, 2016). We are not using the stock exchange viewpoint to do this categorization (Nasdaq, 2012). According to Investopedia (2016), within Asia Pacific, Australia, Canada, Chile, and South Korea are also regarded as developed economies.
} 
empirical analysis of how both knowledge and relational mechanisms simultaneously form configurations that contribute to innovation performance of open innovation firms.

This article attempts to identify the configuration of open innovation strategies ${ }^{3}$ by simultaneously using both knowledge and relational mechanisms (in this study, we operationalize knowledge and relational mechanisms as knowledge and relational dimensions). Setting up of an accurate, detailed but manageable classification system is fundamentally important in any subject discipline, from the more distant field of classical economics (Schumpeter, 1939) to the more recently developed field of innovation (Henderson \& Clark, 1990). This is because if, for example, the classification system is over-simplistic such as categorizing open innovation strategies into outbound and inbound (Gassmann \& Enkel, 2004), empirical studies based on this classification would be potentially misleading. In fact, a classification system that is over-simplistic or incomplete could lead to widespread confusion as to what empirical studies relying on this classification are actually talking about. This would result in "more conflict in empirical results than is factually true, natural, or even possible in empirical research" (Garcia \& Calantone, 2002, p. 111). Henard and Szymanski (2001) also posited that predictor-performance relationships can vary due to changes in measurements as well as contexts.

This study strives to develop and validate a classification system of archetypes of open innovation strategies that is as accurate as it can be, detailed by capturing any subtle differences between different open innovation strategies, but still manageable in the sense that researchers and practitioners alike can adopt without much difficulty. Only after having developed and validated the different archetypes of open innovation strategies, would we start to examine if any of the archetypes produces superior innovation performance.

In addition, innovation process characteristics particularly necessitate inter-firm coordination efforts required to transfer value back to the focal firms, which create challenges for open innovation strategies decisions (Keupp, Palmié, \& Gassmann, 2012; Belderbos, Carree, Diederen, Lokshin, \& Veugelers, 2004). Therefore, following previous literature (Vaidyanathan, Devaraj, \& D'Arcy, 2012; Fang, 2011), we examine two of the most important innovation process characteristics: process interdependence and process complexity. The details of research objectives are described in Table 1.

This study chooses Taiwan as its research setting because, to maintain their competitive advantage in China, firms in Taiwan must continuously collaborate with their external parties to develop new products specific to the Chinese market ( $\mathrm{Li}$, Zheng, \& Wang, 2016; Cheng \& Huizingh, 2014). In addition, compared with other Asia Pacific countries, because of their dependence on industries, such as information technology, electronics, or telecom, that emphasize on innovation, their special but fragile relationship with China, and their "developed economy" status under which bona fide innovation, rather than imitation or cheap labor or abundant natural resources, is key for further growth, firms in Taiwan has been under more pressure to innovate with external parties, in order to introduce new products (Ho, Ghauri, \& Larimo, 2018;

\footnotetext{
${ }^{3}$ For this study, open innovation strategies refer to a strategy which centers on the open innovation firms and is driven by joint efforts involving internal and external parties' willingness to openly share/obtain knowledge assets and benefit from results within the networking relationships (Saebi \& Foss, 2015; Huizingh, 2011).
} 
Table 1 Research objectives and corresponding plans

Research objectives Corresponding plans

1. Can archetypes of open innovation strategies be identified by knowledge and relational mechanisms simultaneously?

Do they differ in their ability to predict innovation success under the condition of innovation process characteristics?
- Using a configurational approach as a tool for constructing empirically-based typologies of open innovation strategies, and then using a cluster analysis to validate the emergence of the five archetypes of open innovation strategies.

- Empirical data provided by 78 open innovation firms and collected from an exploratory study.

- Setting up and testing of H1: Relationship-centric open innovation strategies are expected to have the greatest innovation success, compared with other types of open innovation strategies.

- Setting up and testing of $\mathrm{H} 2$ : When innovation process interdependence is high, relationship-centric open innovation strategies are expected to have the greatest innovation success, compared with other types of open innovation strategies.

- Setting up and testing of H3: When innovation process complexity is high, relationship-centric open innovation strategies are expected to have the greatest innovation success, compared with other types of open innovation strategies.

- Empirical data provided by 248 open innovation firms and collected from a cross-industry survey.

Kafouros, Wang, Piperopoulos, \& Zhang, 2015). Thus, Taiwan provides a rich context for empirical research in open innovation.

What is more, although Taiwan officially is not even a member state within the 46strong-member-states Asia-Pacific region according to the classification of Daniel K. Inouye Asia-Pacific Center for Security Studies (Daniel, 2018) because of the political pressure from People's Republic of China, it is a sovereign state with a self-governing economy. Therefore, its economy and business must not be excluded for academic study purposes. Taiwan is situated along the so-called Pacific Rim and has earned the status as a developed economy. Studies on open innovation and other innovation matters were mostly conducted in developed economies in the western world (we called them traditional developed economies in this paper), but were much less in developed economies in other parts of the world (we called them new developed economies in this paper) such as the Asia-Pacific region. This study can contribute to readdressing this geographical imbalance in open innovation studies.

This study seeks to provide several contributions to the open innovation literature and the Asia Pacific region's economies. First, by developing archetypes of open innovation strategies through the configuration of knowledge and relational dimensions, this study introduces a configurational approach into open innovation research (Meyer, Tsui, \& Hinings, 1993). Second, because different archetypes of open innovation strategies vary in innovation success, this study sheds light on which open innovation strategies is more or less effective for firms. Our results indeed provide further evidence to improve our understanding of how open innovation value for the focal firm (Bogers et al., 2017; Almirall \& Casadesus-Masanell, 2010; Dhanaraj, Lyles, Steensma, \& Tihanyi, 2004). Third, by using large samples in different stages of this study from Taiwan (an exploratory study and cluster analysis of 78 open innovation 
firms) and adopting a robust research design (a face and content validity review, two pilot test, and a cross-industry survey of 248 open innovation firms) in the context of a new developed economy in the Asia-Pacific region, this study addresses the empirical criticism that open innovation has been studied mostly in advanced countries (referring to USA, Canada, Western European countries, and Japan) and much less in other parts of the world (Park, Mezias, Lee, \& Han, 2014; Huizingh, 2011). Therefore, this study expands the geographical scope of open innovation literature to a country (Taiwan) not traditionally regarded as a developed economy and in a region (Asia Pacific) that witnessed comparatively far less research work than in the Western world.

\section{Theory and hypotheses development}

One stream of open innovation research shows that open innovation activities are usually depicting how a firm can leverage on external entities to increase its knowledge learning, profits, and societal impact (e.g., Cassiman \& Valentini, 2016; Li-Ying, Wang, \& Ning, 2016; Dahlander \& Gann, 2010; Laursen \& Salter, 2006). It basically involves the use of inflows and outflows of knowledge to accelerate innovation development, namely, knowledge dimension. Consistent with previous open innovation research that views open innovation development as a process of knowledge management (Gassmann \& Enkel, 2004), we adopt of the lens of the knowledge-based view (Grant, 1996) to use knowledge as a foundational dimension to configure open innovation strategies.

Although knowledge dimension may evolve naturally, the other stream of open innovation research suggests that, with the rise of open innovation activities increasingly involving a multiplicity of practices, relationships do matter in open innovation activities (e.g., Wang, Chang, \& Shen, 2015; Du, Leten, \& Vanhaverbeke, 2014; Liu, Tsou, \& Chen, 2013; Sisodiya et al., 2013). As West and Bogers (2014) note, open innovation activities need relationships to external sources of knowledge inputs. Such relationships facilitate new forms of association and innovation (Bogers et al., 2017). We adopt relational exchange theory, which basically states that relationships generate trust and discourage opportunistic behavior between firms (Macneil, 1980), as the other foundational dimension. Drawing on these two bodies of research, our theoretical baseline is that the configuration of open innovation strategies should simultaneously consider knowledge and relational dimensions.

However, in spite of the recognition of importance of knowledge and relational dimensions in configuring open innovation strategies, research on aligning simultaneously both dimensions has been limited. Considering that empirical research-based information about aligning simultaneously both knowledge and relational dimensions is not available in the existing literatures, we conduct primary qualitative research as the first phase of this large-scale study (an exploratory study and a cluster analysis) to further our understanding in this field. The details will be described in the Research methods section.

Along with the relevant literature (e.g., Cassiman \& Valentini, 2016; Lakemond et al., 2016; Eftekhari \& Bogers, 2015; Ritala et al., 2015; Van Burg et al., 2014; Sisodiya et al., 2013; Gronum et al., 2012; Dahlander \& Frederiksen, 2012; Parida et al., 2012; Huizingh, 2011; Van de Vrande et al., 2009), the first phase research data 
reveal that, first, two knowledge dimensions (knowledge linkages and knowledge complementarity) and three relational dimensions (mutual trust, relational strength, and relational commitment) proved to be fundamental dimensions to categorize 78 open innovation firms examined in the exploratory study. Second, results of the cluster analysis reveal that open innovation firms can be classified as belonging to one of the four archetypes of open innovation strategies: (1) full collaboration, (2) knowledgecentric, (3) relational-centric, and (4) minimal collaboration.

So far, this study identifies the four archetypes of open innovation strategies. However, as noted earlier, the specific innovation process characteristics can significantly affect the effectiveness of open innovation strategies, as we discuss next.

\section{The role of innovation process characteristics}

A lack of common goals among collaborative partners can lead to difficulty in performing open innovation activities (Cheng \& Huizingh, 2014). In addition, compared with Western countries such as the United States, Taiwan is a society of low-trust in business collaboration because high levels of trust tend to exist in close families, not in business partners with no family ties (Chung, 2013). This type of society also exists in many other Asia Pacific countries, such as China, Japan, South Korea, Singapore, Thailand, and Vietnam (Liu, Yang, \& Zhang, 2012). Consequently, common goals and trust generally are lacking among open innovation partners, which create challenges to the implementation of open innovation strategies.

We next discuss how the four archetypes of open innovation strategies are likely to be associated with the innovation success, and how two innovation process characteristics, process interdependence and process complexity, potentially influence these associations.

\section{Differential impacts of the four open innovation strategies on innovation success}

The knowledge-based view assumes that the wealth-creating capacity of firms is based on the knowledge they acquire and retain (Grant, 1996). Knowledge is an intangible asset and firms interpret and integrate new information based on their knowledge frameworks. As most firms need novel and unique knowledge to develop new products/services, they may not have enough of such knowledge to effectively explore/ exploit the potential opportunities of innovation. As such, firms pursue a collaborative innovation process, in which innovative knowledge transfer and acquisition through interfirm linkages is increasingly developed (Bogers et al., 2017).

Open innovation firms cannot possess all fields of knowledge to create the innovations they want, but they can acquire needed or complementary knowledge from external entities (West \& Bogers, 2014; Ferrary, 2011). For example, by using knowledge from customers or suppliers, open innovation firms are able to increase their understanding of the market (De Jong, von Hippel, Gault, Kuusisto, \& Raasch, 2015). By adopting knowledge from external parties, open innovation firms can enhance their ability of new products/services development (Du et al., 2014). This approach of searching and making use of the external knowledge encompasses the notions of knowledge linkages and knowledge-centric (Carlo, Lyytinen, \& Rose, 2012; Fang, 2011). Therefore, it is logical to reason that the more the open innovation firm uses 
knowledge mechanisms to acquire external knowledge, the better the firm is able to create new offerings based on new combinations with external and internal knowledge, and the greater the innovation success.

In contrast, relational exchange theory is based on the concept that parties to an exchange are in mutual agreement that the resulting outcomes of the exchange are greater than those that could be attained through other forms of exchange (Macneil, 1980). Relational exchange is often described as formal, informal, self-enforcing governance, relationalism, or social embeddedness (Dyer \& Singh, 1998). It enhances relational mechanisms that rely on the complementarity of resources among collaboration partners (Sisodiya et al., 2013). In addition, researchers forward the notion that these partners are linked via implicit and explicit dynamic learning alliances or inter-organizational networks/alliances learning (Jarvenpaa \& Wernick, 2011). Relational exchange is, therefore, characterized by shared values, trust, commitment, and behavioral guiding principles. This theoretical domain helps us advance our knowledge of open innovation phenomena that hitherto focuses on the foundation of the knowledge dimension and apparently overlooks the importance of the relational dimension (West et al., 2014).

Building on strong relational mechanisms with external entities can lead to superior innovation performance (Sisodiya et al., 2013). This is mainly because having the relational mechanisms at work enables firms to build and develop a common ground with external entities through a deepening of relationships (West \& Bogers, 2014), which not only aid mutual trust but also enhance relational strength and relational commitment among external entities (Jarvenpaa \& Wernick, 2011). As such, through building strong relationships with external entities, these open innovation firms can easily leverage valuable resources into their innovation process and, thus, result in superior innovation performance. That is, relational and knowledge dimensions complement each other. Particularly, relational dimension facilitates the process and function of knowledge dimension, through the trust, relational embeddedness, and strong ties (Kohtamäki, Partanen, Parida, \& Wincent, 2013), Thus, we posit that open innovation firms that focus mostly on relational dimension while being complemented by knowledge dimension will have greater innovation success. Therefore,

Hypothesis 1 Relationship-centric open innovation strategies are expected to have the greatest innovation success, compared with other types of open innovation strategies.

\section{Moderating effects of innovation process characteristics}

However, which archetypes of open innovation strategies are associated with which level of innovation success is likely to depend on a number of contingencies. An innovation process based on open innovation strategies reflects a joint problem-solving process (Bogers \& Horst, 2014) in which entities work collaboratively during idea generation, concept development, research and development, prototype testing, and, market launch. Therefore, we can decompose the innovation process into a set of interrelated tasks distributed among open innovation entities. Two innovation process characteristics are particularly relevant to the joint problem-solving process: process interdependence and process complexity (Fang, 2011; Mudambi \& Tallman, 2010). 
Under the circumstance triggered by open innovation strategies, the interdependence of the process driven by relationships with external entities and the complexity of the processes engaged by knowledge sharing with these entities are unique to different open innovation firms (Sisodiya et al., 2013; Bogers \& Horst, 2014). Therefore, we propose that process interdependence and process complexity would play an important role in affecting outcome of open innovation strategies.

Process interdependence refers to the extent to which the completion of an innovation task depends on interactions among open innovation entities during the various stages of the innovation process (Srikanth \& Puranam, 2011). When process interdependence is high, external partners' inputs are crucial to complete each task in the new product development process. Process interdependence can minimize relational barriers by enhancing inter-firm relationships (Fang, 2011). Increased familiarity as a result of high process interdependence builds trust, relational strength and commitment, and cooperation, which encourage external entities to share their knowledge during the innovation process (Schleimer \& Shulman, 2011). In addition, a high level of innovation collaboration demanded by high process interdependence creates a foundation on which each partner joins the new product development process (Staudenmayer, Tripsas, \& Tucci, 2005) that facilitates new product success.

In the context of high process interdependence, compared with other types of open innovation strategies, relationship-centric open innovation strategies should be more likely to enhance the focal firms and external entities' knowledge inputs, which are crucial to complete each task in the innovation process, and, thus, contribute to innovation success. This is mainly because research on relational exchange suggests that relational mechanisms that enable such exchange to leverage value of knowledge is the nature of the relationship (Kohtamäki et al., 2013; Nyaga, Whipple, \& Lynch, 2010). Thus, firms that focus on relationship-centric open innovation strategies not only can apply knowledge mechanisms to maximize the effectiveness of process interdependence, but also use relational mechanisms to make the most of process interdependence. Therefore,

Hypothesis 2 When innovation process interdependence is high, relationship-centric open innovation strategies are expected to have the greatest innovation success, compared with other types of open innovation strategies.

Process complexity refers to the extent to which the innovation process is knowledge intensive and technically complicated and requires the broad involvement of open innovation entities (Vaidyanathan et al., 2012). A complex process tends to challenge the existing collaborative structures of both focal firms and external partners, because they must actively search for new and different knowledge to address the complicated innovation development process (Mudambi \& Tallman, 2010). In addition, process complexity in the innovation development process makes it harder to assimilate both focal firms and external partners' complementary knowledge bases, because of the difficulty of integrating different knowledge (Simonin, 1999). Specifically, in association with process complexity, communicating each external partner's contribution to the innovation development process may become unclear (Mudambi \& Tallman, 2010). Such situation may encourage collaborative partners to establish barriers to knowledge integration, 
which would decrease the effectiveness of new product development performance (Fang, 2011).

In situations driven by open innovation strategies, process complexity can result in a lack of mutual trust and relational strength and commitment, which create difficulties to the innovation development (Sisodiya et al., 2013). Open innovation firms must actively utilize their relationships to search for new and different knowledge to address the issue of process complexity. Relationshipcentric open innovation strategies that focus on relational mechanisms should have a competitive advantage in employing relationships to facilitate knowledge integration and new knowledge creation, compared with other archetypes of open innovation strategies. In addition, a satisfactory level of trust and relational strength in relational exchange enables firms to focus on long-term benefits of the relationship and, ultimately, reduces transaction costs associated with knowledge exchange (Nyaga et al., 2010).

In short, with a satisfactory level of inputs in trust and relational strength from relational mechanisms, relationship-centric open innovation strategies are better able to achieve greater innovation success than other architypes of open innovation strategies. Therefore,

Hypothesis 3 When innovation process complexity is high, relationship-centric open innovation strategies are expected to have the greatest innovation success, compared with other types of open innovation strategies.

\section{Research methods}

In this study, we adopt a mixed-methods, four-stage approach. First stage is content analysis of open innovation literature resulting in 12 dimensions of types of open innovation strategies which are then trimmed to have 7 dimensions kept for this study. Second stage is in-depth interviews with 102 responsible individuals across 78 open innovation firms that show consistent differences in 5 out of the 7 dimensions arising from the first stage, and then after a series of further work such as checking with two academics and finding out inter-coder reliability 4 archetypes of open innovation strategies that can be described alongside the 5 dimensions have been developed. Third stage is cluster analysis resulting in four distinct clusters and the labelling of these four clusters as four archetypes of open innovation strategies. Fourth stage is large-scale survey to assess the relative impacts of the four archetypes of open innovation strategies on innovation performance with the moderating process variables in the analysis. Elaboration of these four stages is as follows.

\section{First stage content analysis}

We first followed previous researchers in innovation-related management (e.g., Liang, Li, Yang, Lin, \& Zheng, 2013), using a configurational approach as a tool for constructing empirically-based typologies of open innovation strategies. Second, a 
content analysis of the open innovation literature identified the dimensions of types of open innovation strategies. As a result, 12 dimensions were identified. ${ }^{4}$

The two co-authors of this study and two academics discussed which of the 12 dimensions derived from the literature could be used to differentiate persistent differences among different types of open innovation strategies. As a result of these deliberations, five dimensions were removed, leaving the other seven dimensions for further consideration.

\section{Second stage in-depth interviews}

We conducted 102 in-depth interviews to obtain empirical evidence from a case studybased investigation of 78 open innovation firms. After analyzing the interview data from these 78 open innovation firms, manually and electronically (NVivio 9), we agreed that we have arrived at theoretical saturation (Shiu, Hair, Bush, \& Ortinau, 2009), as further collection and analysis of data from more open innovation firms was not likely to yield further insights. The analysis of the 78 open innovation firms established that, of the seven dimensions derived from the previous steps, two dimensions did not display strong enough variation in their manifestation levels across the 78 open innovation firms to ensure their further consideration for establishing whether types of open innovation strategies could be identified. The remaining five dimensions showed persistent differences among the 78 open innovation firms: knowledge linkages, knowledge complementarity, mutual trust, relational strength, and relational commitment.

To advance the results of the coding process in terms of reliability and validity, we asked another two academics, with backgrounds in qualitative research methods, to analyze interview results derived from the 78 open innovation firms. We then checked inter-coder reliability based on both the total number of units and the total number of exact matches in units coded by the two academics. The value of inter-coder reliability was acceptable (Cohen's kappa $=.95$ ). The results suggest that knowledge linkages, knowledge complementarity, mutual trust, relational strength, and relational commitment are ideal dimensions to categorize different types of open innovation strategies.

Finally, we classified each of the 78 open innovation firms as a high/moderate/low profile across two knowledge dimensions and three relational dimensions. As a result, four archetypical open innovation strategies emerged along the five dimensions. Table 2 demonstrates the four archetypical profiles.

\section{Third stage cluster analysis}

We used a cluster analysis to validate the emergence of the four open innovation strategies. We hired three academics to study the 78 open innovation firms and rate them on a scale from 1 to 10 under the five dimensions. Based on guidelines in Milligan and Sokol (1980) and Punj and Stewart (1983), we used a hierarchical analysis followed by a k-means analysis to obtain taxonomies that are as stable and

\footnotetext{
${ }^{4} 1$. knowledge linkages, 2. knowledge complementarity, 3. knowledge rarity, 4. knowledge tasks, 5. knowledge structuring, 6. relationship stability, 7. mutual trust, 8. relational strength, 9. relational commitment, 10. joint action, 11. flexibility, and 12. reciprocity.
} 
Table 2 Dimensions and types of open innovation strategies

\begin{tabular}{lllll}
\hline Dimensions/Types & $\begin{array}{l}\text { Full } \\
\text { collaboration }\end{array}$ & Relationship-centric & Knowledge-centric & $\begin{array}{l}\text { Minimal } \\
\text { collaboration }\end{array}$ \\
\hline $\begin{array}{l}\text { Knowledge dimension } \\
\text { Knowledge linkages } \\
\text { Knowledge complementarity }\end{array}$ & High (8.37) & Moderate (6.12) & High (9.56) & Low (2.84) \\
$\begin{array}{l}\text { Relational dimension } \\
\text { Mutual trust }\end{array}$ & Moderate (5.99) & High (9.32) & Low (3.26) \\
$\begin{array}{l}\text { Relational strength } \\
\text { Relational commitment }\end{array}$ & High (9.06) & High (8.97) & Moderate (5.47) & Low (3.09) \\
\hline
\end{tabular}

Mean scores are reported in parentheses

The mean scores between 1 and 3.3 is categorized into Low, between 3.4 and 6.6 is categorized into Moderate, and between 6.7 and 10 is categorized into High

Specifically, for Minimum collaboration open innovation strategies, their mean scores of the five subdimensions are all at least 2.84. This shows that even though these firms do not want to achieve a higher level of any of the five sub-dimensions, they still need to attain the minimum acceptable levels in all these subdimensions in order to succeed in their open innovation strategies

robust as possible. Regarding the hierarchical approach, we used Ward's method based on squared Euclidian distances, which creates clusters of similar size.

We considered a range of initial solutions from the hierarchical analysis with either three, four, five, six, or seven groups, as suggested by the dendrogram. The number of clusters was selected based on the within-group sum of squares (Hair, Tatham, Anderson, \& Black, 2013). To assess which solution was the most stable, we then computed kappa between each initial and final solution (Singh, 1990). The four-cluster solution appeared to best fit the data $(k=.97$, while $k<.86$ for other solutions). Three- and Five-cluster solutions were discarded based on the clustering statistics of the root-mean-square standard deviation (measuring the homogeneity of the cluster formed).

We also used a non-hierarchical analysis as a robustness check, and find that both hierarchical and non-hierarchical analyses gave the same results. Finally, we validated the results by using Kruskal-Wallis tests and found significant differences $(p<.01)$ between the variables used to develop the clusters (Hair et al., 2013), suggesting that these results were robust.

In cluster 1, open innovation strategies are strongly involved in both high levels of two knowledge dimensions and three relational dimensions: high knowledge linkages, high knowledge complementarity, high mutual trust, high relational strength, high relational commitment. They are the strongest in both knowledge and relational dimensions as opposed to the other four clusters. Evidenced by their high scores in the four clustering variables overall, it is fair to suggest that this cluster of firms creates innovation through intensively interacting with external entities, as well as widely employing external knowledge. We therefore label them as full collaboration.

Firms in cluster 2 have moderate levels of two knowledge dimensions, with high levels of three relational dimensions: moderate knowledge linkages, moderate knowledge complementarity, high mutual trust, high relational strength, and high relational 
commitment. They focus more on relationship activities in open innovation activities. Therefore, we label them as relationship-centric.

Open innovation strategies in cluster 3 have high levels of two knowledge dimensions, with moderate levels of relational dimensions: high knowledge linkages, high knowledge complementarity, moderate mutual trust, moderate relational strength, and moderate relational commitment. Because they focus more on the transformation of knowledge into innovation processes than relational dimensions, we label them as knowledge-centric. ${ }^{5}$

Finally, cluster 4 includes open innovation strategies that generally rely only slightly on two knowledge and three relational dimensions: low knowledge linkages, low knowledge complementarity, low mutual trust, low relational strength, and low relational commitment. These firms tend to be aware of the benefits of using open innovation activities, but they score weakly on the knowledge and relational dimensions overall when taking on new open innovation opportunities. They are definitely more restricted than other types of open innovation strategies. Therefore, we label them as minimal collaboration.

\section{Fourth stage large-scale survey}

\section{Sample and data collection}

Based on the commercial list available on subscription from China Credit Information Service (2013) in Taiwan, we developed a contact list of the top 1000 Taiwanese firms in terms of sales. To capture inter-industry variability, the sampling frame was not restricted to any given industry.

We contacted each firm by telephone to determine whether it had employed open innovation strategies in its innovation process. To avoid an arbitrary selection of a particular archetype of open innovation strategy, top senior managers were asked to identify a completed open innovation project, launched between 2010 and 2012, and to respond to the items as they are related to that particular open innovation project. As a result of this process, 392 firms were eligible and agreed to participate in this study.

As with previous studies in developing economies (e.g., De Luca \& AtuaheneGima, 2007), we collected the data on-site, so that we could clarify any questions that the respondents might have and ensure that the questionnaires collected were complete and usable. We recruited trained interviewers to conduct on-site surveys, who presented the questionnaires to the respondents. To reduce potential common method bias (Podsakoff, MacKenzie, \& Podsakoff, 2012), we obtained different information from multiple sources in each firm. Specifically, data for open innovation strategies were collected from top senior managers, data for process interdependence, process complexity, and new product/service development speed were collected from new product/ service development managers, and data for new product/service innovativeness and market performance were collected from marketing managers. All respondents were asked to fill in the questionnaire based on the open innovation project and to respond to

\footnotetext{
${ }^{5}$ Knowledge-centric and relationship-centric mean focusing more on knowledge or relationship respectively but still possessing relevant levels of relationship or knowledge respectively in the respective open innovation strategies.
} 
the items as they are related to that particular open innovation project. This design ensures that the data are obtained from the most appropriate sources.

This leads to 248 sets of matched responses from top senior managers, new product/ service development managers, and marketing managers, resulting in an effective response rate of $63.2 \%$ (248 out of 392). The sample represented six industries: information technology $(22.5 \%)$, banking and insurance $(21.3 \%)$, electronics $(18.5 \%)$, telecom $(17.3 \%)$, semiconductor $(16.5 \%)$, and others $(3.9 \%)$.

\section{Measures}

All items were measured on a seven-point scale. We used the double-translation method (Yang, Dess, \& Robins, 2018) to translate the questionnaire from English into Mandarin (English-Mandarin-English). Specifically, we first developed an English version of the questionnaire, then used a double-translation procedure to translate it into Mandarin (English-Mandarin-English). This process included: (1) the authors initially translating the items into Mandarin; (2) three academics translating the Mandarin version back into English; and, (3) another two academics checked the translations to ensure conceptual equivalence. The same procedures are repeated for the questionnaire from Mandarin into English (Mandarin-English-Mandarin).

In addition, we conducted a face and content validity review $(N=18)$, the first pilot test $(N=69)$ to indicate any ambiguity respondents experienced when responding to the items, and the second pilot test $(N=93)$ to purify the scale and to obtain preliminary estimates of reliability. Next, we proposed a protocol on the basis of the interview results to describe high, moderate, and low levels of knowledge linkages, knowledge complementarity, mutual trust, relational strength, and relational commitment. ${ }^{6}$

We developed the measure for assessing different archetypes of open innovation strategies based on the protocol used in the exploratory study. During the survey, top senior managers were asked to identify their most successful open innovation strategy between 2010 and 2012 and then to rate their strategy on a scale from 1 to 7 under the five dimensions (knowledge linkages, knowledge complementarity, mutual trust, relational strength, and relational commitment). Following the same procedure of the cluster analysis, our sample consisted of 70 full collaboration open innovation strategies (28.2\%), 68 knowledge-centric open innovation strategies (27.4\%), 65 relationship-centric open innovation strategies $(26.2 \%)$, and 45 minimal collaboration open innovation strategies (18.1\%).

Process interdependence was adapted from Fang (2011) with four items $(\alpha=.89)$. A sample item is "During the development process of the product/service, both external entities and we have to work very closely in each stage of the new product/service development project". Process complexity was adapted from Griffin (1997) with three items $(\alpha=.86)$. A sample item is "Compared to other new product/service development process, the development process of this product/service is: Simple-Complex".

Innovation success was measured by four indicators: financial performance, new product/service development speed, market performance, and new product/service

\footnotetext{
${ }^{6}$ Details of the face and content validity review, the first pilot test, the second pilot test as well as the protocol are not included in this paper which is already very long. Any reader interested in knowing these details is welcome to contact the authors.
} 
innovativeness. Data for financial performance originated from the data reported by China Credit Information Service (2013). The firms' financial performance was measured by the percentage of profits attributable to new products/services launched between 2010 and 2012. New product/service development speed was adapted from Rindfleisch and Moorman (2001) with four items $(\alpha=.88)$. A sample item is "Please evaluate the product/service launched to markets in the past three years on: Much slower than we expected-Much faster than we expected". Market performance was adapted from Blazevic and Lievens (2004) with three items $(\alpha=.85)$. A sample item is "Relative to competing firms' performance, your firm's market performance is very successful in terms of Reputation". New product/service innovativeness was adapted from Lee and Colarelli O'Connor (2003) with three items $(\alpha=.84)$. A sample item is "The benefits this new product/service offers are new to the customers".

We controlled for firm industry type, firm size, firm age, and environmental turbulence. Based on the data from China Credit Information Service (2013), we determined each responding firm's industry type, firm size, and firm age. For firm industry type, the sampling units were categorized into service and manufacturing firms, depending on whether the majority of a firm's sales are derived from service or tangible products (Ettlie \& Rosenthal, 2011). For firm size, we followed the definition of Small and Medium Enterprise Administration by Ministry of Economic Affairs, Taiwan, in which firms with fewer than 200 employees were classified as small firms, while firms with 200 employees or above were large firms. Firm age was measured as the number of years since the firm had started its business operation. Environmental turbulence was adapted from De Luca and Atuahene-Gima (2007) with five items $(\alpha=.93)$. A sample item is "In the markets in which the innovation operates, Customer's preferences change rapidly over time".

\section{Analysis and results}

The MPlus exploratory structural equation modeling (SEM) technique (Muthen \& Muthén, 2010) was used to establish the internal consistency of our measures, because it combines exploratory and confirmatory factor analysis in one procedure, and avoids the problems associated with the traditional two-step process (Fornell \& Yi, 1992). Based on the fit indexes, the model fit is satisfactory: $\chi^{2} /$ d.f. $=1.92$; comparative fit index $(\mathrm{CFI})=.95$, goodness of fit $(\mathrm{GFI})=.94$; Tucker-Lewis index $(\mathrm{TLI})=.93$; incremental fit index $($ IFI $)=.95$; root mean square error of approximation $($ RMSEA $)=.04$. In addition, the items load as expected and all factor loadings are significant $(p<.01)$ on their latent factors.

Discriminant validity was assessed by using the Fornell and Larcker (1981) procedure and an alternative procedure that Anderson and Gerbing (1988) recommend. For each construct the value of the square root of each average variance extracted (AVE) is greater than the values of the inter-construct correlations. In addition, the confidence interval does not include 1.0 by plus or minus two standard errors around the correlation between the constructs (Anderson \& Gerbing, 1988), and the Chi-square test between any two constructs is significant $(p<.001)$. Table 3 shows a summary of respondent firms' statistics and correlations. 
Table 3 The basic descriptive statistics and correlations

\begin{tabular}{|c|c|c|c|c|c|c|c|c|c|c|c|}
\hline Variables & Mean & S.D. & 1 & 2 & 3 & 4 & 5 & 6 & 7 & 8 & 9 \\
\hline 1 Financial performance $(\%)$ & 53.7 & 9.73 & - & & & & & & & & \\
\hline $\begin{array}{l}2 \text { New product/service development } \\
\text { speed }\end{array}$ & 4.84 & 1.37 & .12 & .78 & & & & & & & \\
\hline 3 Market performance & 4.39 & 1.12 & $.22 *$ & $.20 *$ & .80 & & & & & & \\
\hline 4 New product/service innovativeness & 4.72 & 1.43 & $.25 *$ & $.21^{*}$ & .13 & .78 & & & & & \\
\hline 5 Process interdependence & 4.96 & 1.29 & .07 & .13 & .10 & .09 & .81 & & & & \\
\hline 6 Process complexity & 5.09 & 1.36 & .06 & .11 & .07 & .12 & .15 & .81 & & & \\
\hline 7 Firm size (log) & 4.01 & 2.69 & $.19^{*}$ & .09 & .14 & .10 & .03 & .02 & - & & \\
\hline 8 Firm age $(\log )$ & 4.35 & 2.25 & $.24 *$ & .13 & $.21 *$ & .03 & .04 & .04 & .09 & - & \\
\hline 9 Environmental turbulence & 5.28 & 1.12 & $-.20 *$ & $-.22 *$ & $-.18^{*}$ & $-.19 *$ & .11 & .09 & .11 & .07 & .79 \\
\hline
\end{tabular}

$* p<.05$, ** $p<.01$; S.D.: standard deviation

Bold figures on the diagonal are the square root of the AVE; $N=248$

To assess the differences in innovation success among the four archetypes of open innovation strategies, we followed the procedures of Cheng and Huizingh (2014) by using a SEM approach to assess their main effects.

As shown in Table 4, the $R^{2}$ values of financial performance, new product/service development speed, market performance, and new product/service innovativeness are $.403, .437, .584$, and .562 , respectively, all of which are between moderate and high, indicating that the model explains a substantial proportion of variance in the innovation success variables (Hair et al., 2013). In addition, the path estimate results with $t$-values of full collaboration, relationship-centric, knowledge-centric,

Table 4 Results of main effects of four types of open innovation strategies

\begin{tabular}{|c|c|c|c|c|}
\hline $\begin{array}{l}\text { Innovation success/Path } \\
\text { coefficients(t-value) }\end{array}$ & $\begin{array}{l}\text { Financial } \\
\text { performance } \\
R^{2}=.403\end{array}$ & $\begin{array}{l}\text { New product/service } \\
\text { development speed } \\
R^{2}=.437\end{array}$ & $\begin{array}{l}\text { Market } \\
\text { performance } \\
R^{2}=.584\end{array}$ & $\begin{array}{l}\text { New product/service } \\
\text { innovativeness } \\
R^{2}=.562\end{array}$ \\
\hline \multicolumn{5}{|l|}{ Antecedents } \\
\hline Full collaboration & $.353 * * *(3.828)$ & $.345 * * *(3.745)$ & $.389 * * *(4.301)$ & $.376 * * *(4.118)$ \\
\hline Relationship-centric & $.402 * * *(4.676)$ & $.413 * * *(4.754)$ & $.439 * * *(4.945)$ & $.422 * * *(4.847)$ \\
\hline Knowledge-centric & $.314 * * *(3.502)$ & $.319 * * *(3.511)$ & $.375 * * *(4.112)$ & $.338 * * *(3.729)$ \\
\hline Minimal collaboration & $.206^{*}(2.231)$ & $.216^{*}(2.456)$ & $.243 * *(2.848)$ & $.217 *(2.468)$ \\
\hline \multicolumn{5}{|l|}{ Control variables } \\
\hline $\begin{array}{l}\text { Firm industry } \\
\text { (manufacturing) }\end{array}$ & $.121(1.677)$ & $.112(1.462)$ & $.107(1.313)$ & $.113(1.468)$ \\
\hline Firm industry (service) & $.131(1.762)$ & $.116(1.501)$ & $.136(1.785)$ & $.127(1.690)$ \\
\hline Firm size & $.106(1.306)$ & $.107(1.311)$ & $.114(1.506)$ & $.108(1.318)$ \\
\hline Firm age & $.109(1.327)$ & $.117(1.538)$ & $.103(1.277)$ & .104 (1.297) \\
\hline Environmental turbulence & $-.116(1.519)$ & $-.123(1.612)$ & $-.136(-1.795)$ & $-.145(-1.813)$ \\
\hline
\end{tabular}

$* p<.05 ; * * p<.01 ; * * * p<.001$ 
and minimal collaboration open innovation strategies are significantly and positively related to all four indicators of innovation success. This suggests that the four archetypes of open innovation strategies examined in this study are positively associated with innovation success.

We then compared the relative strengths of the four open innovation strategies through a series of Chi-square difference tests. Specifically, to obtain the Chi-square value of the direct effect of full collaboration open innovation strategy, the first model includes the paths (1) full collaboration open innovation strategy-financial performance, (2) relationship-centric open innovation strategy-financial performance, (3) knowledge-centric open innovation strategy-financial performance, (4) minimal collaboration open innovation strategy-financial performance. The second model deletes the first path from the first model. We thus obtained a Chi-square difference value between the first and second models. Based on these Chi-square values, we again run Chi-square tests to compare the difference (Harmancioglu, 2009). The same procedures are repeated for the other archetypes of open innovation strategies.

As presented in Table 5, a significant positive Chi-square difference indicates that the selected archetype of open innovation firm has a stronger effect on innovation success, while a negative difference suggests a weaker performance. For example, in the first column of Table 5, which focuses on financial performance, the Chi-square difference of full collaboration vs. knowledge-centric is $-4.85^{*}$, suggesting that full collaboration is less effective than relationship-centric.

Accordingly, the differences in innovation success among the four archetypes of open innovation strategies are all significant. Particularly, the results show that relationship-centric open innovation strategy has the strongest impact on innovation success, followed by full collaboration, knowledge-centric, and minimal collaboration open innovation strategies. Table 6 concludes the ranking of the relative effects of the four archetypes of open innovation strategies. The result suggests that Hypothesis 1 is supported.

We then used pairwise comparisons based on general linear model to test Hypotheses 2 and 3. The results shown in Table 7 indicate that Hypothesis 2 is supported, while Hypothesis 3 is partially supported at the statistical significance levels of $p<.001$. We discuss the results in more detail in the following sections.

\section{Discussion}

The importance of open innovation strategies has been well documented (West \& Bogers, 2014), but not all open innovation strategies turned out to be productive. We offer a new perspective on classification of open innovation strategies by simultaneously integrating knowledge and relational dimensions to predict innovation success, while considering the moderating role of innovation process characteristics. In retrospect, this study has met the first research objective by successfully identifying four distinctive archetypes of open innovation strategies via a configurational approach of 78 firm sample data on three knowledge dimensions and two relational dimensions. The second research objective has also been fulfilled by testing Hypotheses 1, 2, and 3. The major findings and their implications for open innovation literature are discussed in this section. 


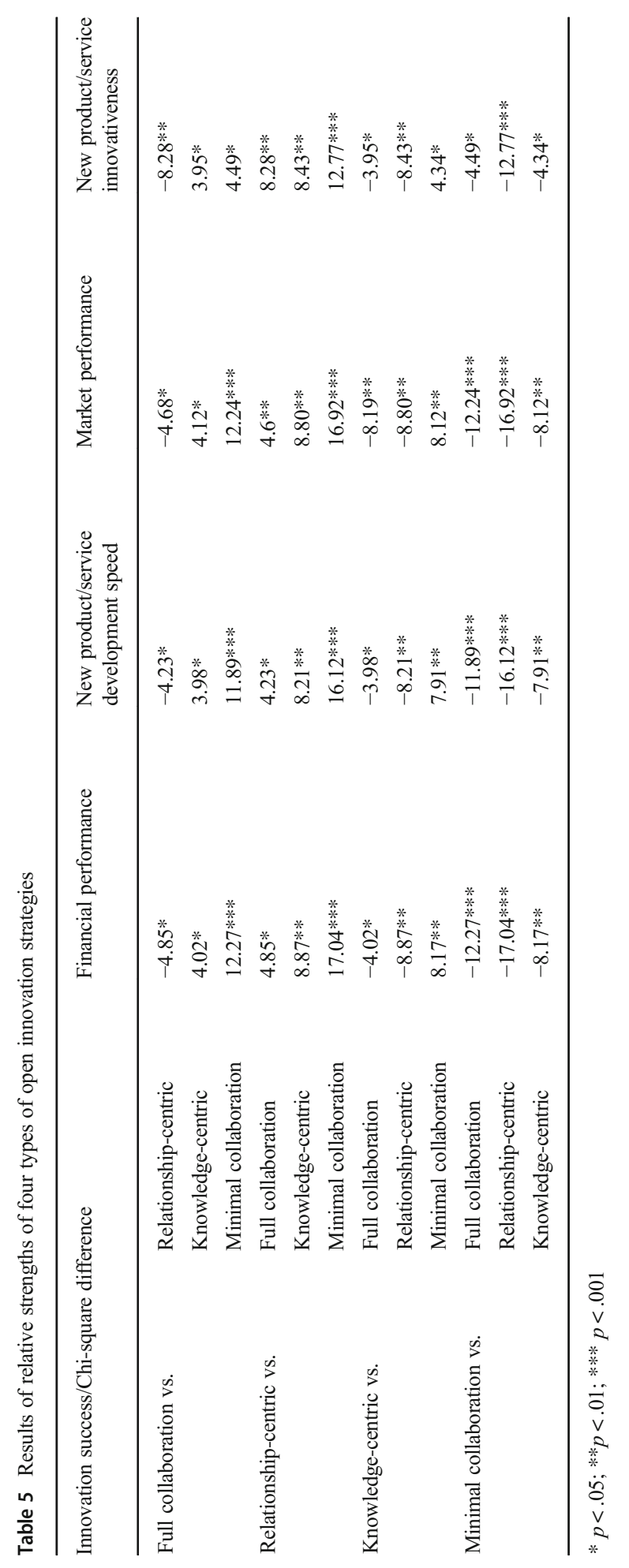


Table 6 Ranking of the relative effects of the four types of open innovation strategies

\begin{tabular}{lllll}
\hline Open innovation strategies & $\begin{array}{l}\text { Financial } \\
\text { performance }\end{array}$ & $\begin{array}{l}\text { New product/service } \\
\text { development speed }\end{array}$ & $\begin{array}{l}\text { Market } \\
\text { performance }\end{array}$ & $\begin{array}{l}\text { New product/service } \\
\text { innovativeness }\end{array}$ \\
\hline Relationship-centric & 1 & 1 & 1 & 1 \\
Full collaboration & 2 & 2 & 2 & 2 \\
Knowledge-centric & 3 & 3 & 2 & 3 \\
Minimal collaboration & 4 & 4 & 3 & 4 \\
\hline
\end{tabular}

Our data analysis indicates that the differential strengths of the impacts of the four archetypes of open innovation strategies on innovation success are all significant. In particular, we expectedly find that relationship-centric open innovation strategies to be the most successful among the four open innovation strategies. Two possible explanations for this finding are discussed.

One possibility is that the innovation maturity concept plays a strong hand in this result. Firms implementing open innovation strategies require cycles of continuous improvement to increase their open innovation capability, thereby also increasing their open innovation maturity (Enkel, Bell, \& Hogenkamp, 2011). Open innovation maturity, which is fundamentally based on the Innovation Capability Maturity Model (Essman \& Du Preez, 2009), is used to support identification of the evolution level reached by open innovation strategies at a given moment, ranging from immature, to medium-mature, to mature. Thus, firms adopting knowledge-centric open innovation strategy in this study are expected to be the fastest in the maturity level of the knowledge mechanism, implying that their open innovation strategies of knowledge linkages and knowledge complementarity should be the most formalized, compared with relationship-centric open innovation strategy.

While firms adopting full collaboration open innovation strategy are also expected to reach the maturity level of both knowledge and relational dimensions, the effects of the two dimensions could offset each other or run in a way that their positive interaction effect may be eliminated (Mohr \& Sengupta, 2002), which then hinder the overall level of innovation success (Hernández-Espallardo, Sánchez-Pérez, \& Segovia-López, 2011). This is because, as Mohr and Sengupta (2002) argue, given a sufficient degree of closeness in an inter-firm relationship, the focal firm may risk losing some of its valuable knowledge.

A field example from one of our respondent firms who has practiced full collaboration open innovation strategy more than eight years put forward the following painful expression: "in order to maximize the efficiency of relationships with partners, we want to learn as much as possible from our partners. However, we eventually lose our sources of competitive advantage because of leaking our critical knowledge to some of the partners." This demonstrates the existence of a paradox in full collaboration open innovation strategy in terms of open innovation maturity.

The other possible explanation for this finding may be gleaned from the study of Zhou and Li (2012) who, based on the knowledge-based view, argue that when a firm obtains a wide variety of knowledge from external entities, the firm could create a new and radical perspective on its existing knowledge. However, while firms that use 


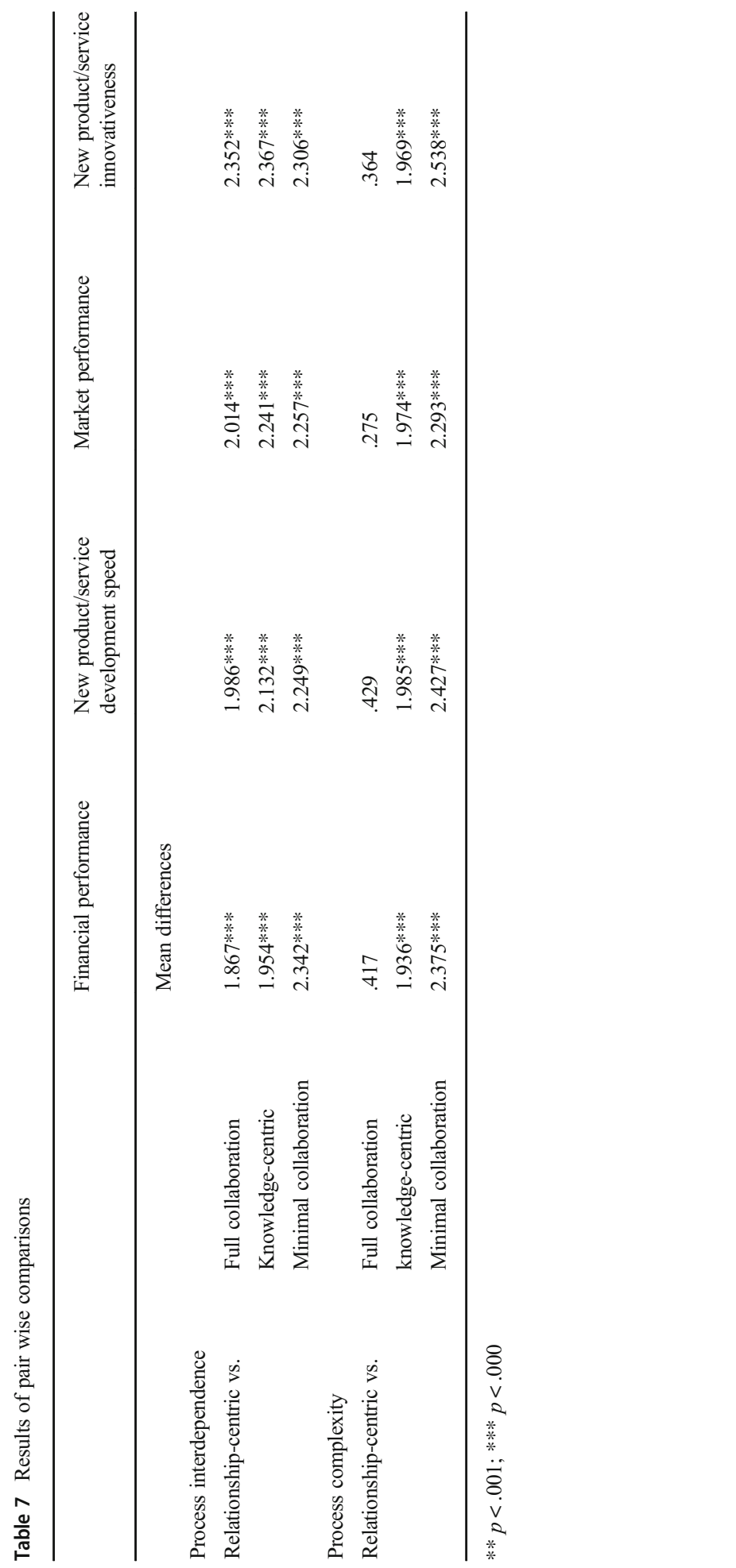


knowledge-centric open innovation strategy could devote the full energy to possess a wider array of external knowledge, it is very likely to enable them to have a negative effect on innovation performance due to organizational inertia (Zhou \& $\mathrm{Li}, 2012$ ). In contrast, firms adopting full collaboration open innovation strategy have to focus on high levels of both knowledge and relational dimensions stretching their resources and capabilities to the limit. This lets them being confusion to the corporate objective, structure, and system of the entire organization (Ferray, 2011).

As for minimal collaboration open innovation strategies, its effects on innovation success have no negative or insignificant values. This finding implies that despite the different approaches taken by different open innovation strategies in terms of knowledge or relational dimensions, employing open innovation strategies as a whole is still a promising way to achieve superior innovation success (Huizingh, 2011; Bogers et al., 2017). This finding sharply contrasts the mixed results in previous studies. We posit that these mixed results are due to the over-simplified categorizations as well as the different categorization systems used in different studies. This highlights the necessity of considering both knowledge and relational dimensions simultaneously for categorizing different open innovation strategies.

Finally, our results indicate that the different impact of different open innovation strategies on innovation success depends on two innovation process characteristics: process interdependence and process complexity. This result appears to support the argument that high process interdependence requires external partners to interact across multiple stages of the innovation process (Schleimer \& Shulman, 2011), while high process complexity requires external partners with even a higher level of knowledge intensity during the collaborative innovation process (Mudambi \& Tallman, 2010). These results highlight the importance of integrating the innovation process characteristics literature to understand the effect of open innovation strategies on innovation success.

\section{Theoretical implications}

The results have significant implications for three research streams. First, by tapping into both the knowledge-based view (Grant, 1996) and relational exchange theory (Macneil, 1980), we have succeeded in developing a typology of open innovation strategies, demonstrating the robustness of this typology, and showing that different archetypical open innovation strategies are associated with different levels of innovation success. As such, this study enriches the open innovation literature by highlighting the value of adopting a configurational approach (Meyer et al., 1993) to understand different archetypes of open innovation strategies. This typology of open innovation strategies also provides a theoretical and empirical framework for future studies.

Second, we clarify how and why both knowledge and relational dimensions matter in open innovation strategies by showing that open innovation strategies can be more delicately defined using the additional relational characteristics for overcoming the drawbacks of purely knowledge-driven approaches. Our findings suggest that our typology based on both knowledge and relational dimensions can be a stable predictor of innovation success. In doing so, we extend research on open innovation literature (Bogers et al., 2017; West et al., 2014; Chesbrough, 2012) by examining the knowledge and relational dimensions simultaneously in 
categorizing different archetypes of open innovation strategies. This new insight implies that knowledge and relational dimensions adopted together can provide a finely tuned categorization of open innovation strategies.

Third, our results imply the need for innovation researchers to rethink open innovation strategies when designing research to explain innovation success. Especially, our findings emphasize the need for open innovation researchers to adopt a contingency perspective in their research (Huizingh, 2011). Our empirical evidence suggests that process interdependence and process complexity contingencies should be taken into account by researchers interested in explaining the innovation success that is created by certain open innovation strategies. This could serve as further evidence to account for the mixed results of performing open innovation strategies. In this respect, this study expands the body of literature on the possible contingent factors that determine the outcomes of open innovation strategies (Sisodiya et al., 2013; Cheng \& Huizingh, 2014).

\section{Managerial implications}

Our study provides managers with useful insights for their choice of open innovation strategies. First, the configuration of open innovation strategies can vary (e.g., as low, moderate, high across the five dimensions in Table 2), and our findings show that such variations can correspond with variations in innovation success created by these open innovation strategies. Therefore, managers should recognize that they need to understand the configuration of their existing open innovation strategy, and know what configuration they need for a new open innovation strategy.

Second, when deciding on which archetype of open innovation strategies to use to create superior innovation success, managers should realize that, other things being equal, certain open innovation strategies will be more effective than alternative ones in achieving innovation success. However, as found in this study, this causal relationship is not straightforward as it will be moderated by both process interdependence and process complexity. Results of these moderating effects leads to three managerial recommendations. First, if process interdependence is high, relationship-centric open innovation strategy should be used. Second, if process complexity is high, a full open innovation strategy is preferable. Third, irrespective of the scorings on the process interdependence and process complexity, the minimal collaboration strategy is always less effective than the other archetypes of strategies.

Third, although the relationship-centric open innovation strategy is found to be the most effective, firms should be cautioned not to downplay the importance of the role of their knowledge mechanisms with their external entities. Firms adopting this strategy should still invest a satisfactory amount of their resources in knowledge building in order to establish an acceptable (moderate) level of knowledge mechanisms which is beneficial for their pursuit of knowledge transfer and acquisition.

\section{Limitations and future research}

This study has several limitations, which open up opportunities for future research. First, while we find that the four archetypes of open innovation strategies are significantly and positively associated with all four indicators of innovation success, the open 
innovation literature has recently proposed an important issue regarding type of open innovation partners (Bogers et al., 2017). Due to data limitations, we could not examine the implications of each type of partners. More research is required to examine the combinatory use of different dimensions, such as different types of partners and knowledge characteristics, to differentiate among different archetypes of open innovation strategies.

Second, although we find that minimal collaboration open innovation strategies are generally underperforming, some firms consciously use this archetype of open innovation strategy to match their business context. Future research could explore why and when firms prefer to use the minimal collaboration option as their open innovation strategy.

Third, there might be an issue with the endogeneity of open innovation strategies. For example, the open innovation maturity framework (Enkel et al., 2011) claims that open innovation strategy is a function of the time and efforts firms have been investing in open innovation management. Therefore, open innovation firm characteristics, such as open innovation experience, may contribute to a firm's relevant decision to adopt a particular open innovation strategy. Future studies can assess the potential impact of open innovation maturity.

Open Access This article is distributed under the terms of the Creative Commons Attribution 4.0 International License (http://creativecommons.org/licenses/by/4.0/), which permits unrestricted use, distribution, and reproduction in any medium, provided you give appropriate credit to the original author(s) and the source, provide a link to the Creative Commons license, and indicate if changes were made.

\section{References}

Almirall, E., \& Casadesus-Masanell, R. 2010. Open versus closed innovation: A model of discovery and divergence. Academy of management review, 35(1): 27-47.

Anderson, J., \& Gerbing, D. 1988. Structural equation modeling in practice: A review and recommended twostep approach. Psychological bulletin, 103(3): 411-423.

Belderbos, R., Carree, M., Diederen, B., Lokshin, B., \& Veugelers, R. 2004. Heterogeneity in R\&D cooperation strategies. International journal of industrial organization, 22(8-9): 1237-1263.

Blazevic, V., \& Lievens, A. 2004. Learning during the new financial service innovation process-antecedents and performance effects. Journal of Business Research, 57(4): 374-391.

Bogers, M., \& Horst, W. 2014. Collaborative prototyping: Cross-fertilization of knowledge in prototypedriven problem solving. Journal of Product Innovation Management, 31(4): 744-764.

Bogers, M., Zobel, A. K., Afuah, A., Almirall, E., Brunswicker, S., Dahlander, L., et al. 2017. The open innovation research landscape: Established perspectives and emerging themes across different levels of analysis. Industry and Innovation, 24(1): 8-40.

Carlo, J., Lyytinen, K., \& Rose, G. 2012. A knowledge-based model of radical innovation in small software firms. MIS Quarterly, 36(3): 865-895.

Cassiman, B., \& Valentini, G. 2016. Open innovation: Are inbound and outbound knowledge flows really complementary? Strategic Management Journal, 37(6): 1034-1046.

Cheng, C., \& Huizingh, E. 2014. When is open innovation beneficial? The role of strategic orientation. Journal of Product Innovation Management, 31(6): 1235-1253.

Chesbrough, H. 2012. Open innovation: Where we've been and where we're going. Research-Technology Management, 55(4): 20-27.

China Credit Information Service 2013. 2013 business groups in Taiwan. Taipei:China Credit Information Service.

Chung, H. M. 2013. The role of family management and family ownership in diversification: The case of family business groups. Asia Pacific Journal of Management, 30(3): 871-891. 
Dahlander, L., \& Frederiksen, L. 2012. The core and cosmopolitans: A relational view of innovation in user communities. Organization science, 23(4): 988-1007.

Dahlander, L., \& Gann, D. 2010. How open is innovation? Research Policy, 39(6): 699-709.

Daniel K. 2018. Inouye Asia-Pacific Center for Security Studies, Countries of the Asia-Pacific region, Retrieved on 12 September 2018 from https://apcss.org/about-2/ap-countries/. Accessed 12 Sept 2018.

De Jong, J. P., von Hippel, E., Gault, F., Kuusisto, J., \& Raasch, C. 2015. Market failure in the diffusion of consumer-developed innovations: Patterns in Finland. Research Policy, 44(10): 1856-1865.

De Luca, L., \& Atuahene-Gima, K. 2007. Market knowledge dimensions and cross-functional collaboration: Examining the different routes to product innovation performance. Journal of Marketing, 71(1): 95-112.

Dhanaraj, C., Lyles, M. A., Steensma, H. K., \& Tihanyi, L. 2004. Managing tacit and explicit knowledge transfer in IJVs: The role of relational embeddedness and the impact on performance. Journal of international business studies, 35(5): 428-442.

Du, J., Leten, B., \& Vanhaverbeke, W. 2014. Managing open innovation projects with science-based and market-based partners. Research Policy, 43(5): 828-840.

Dyer, J., \& Singh, H. 1998. The relational view: Cooperative strategy and sources of interorganizational competitive advantage. Academy of management review, 23(4): 660-679.

Eftekhari, N., \& Bogers, M. 2015. Open for entrepreneurship: How open innovation can foster new venture creation. Creativity and Innovation Management, 24(4): 574-584.

Enkel, E., Bell, J., \& Hogenkamp, H. 2011. Open innovation maturity framework. International Journal of Innovation Management, 15(6): 1161-1189.

Essman, H., \& Du Preez, N. 2009. Practical cases of assessing innovation capability with a theoretical model: The process and findings. In 23rd Annual SAIIE Conference Conference Proceedings (pp. 42-56).

Ettlie, J., \& Rosenthal, S. 2011. Service versus manufacturing innovation. Journal of Product Innovation Management, 28(2): 285-299.

Fang, E. 2011. The effect of strategic alliance knowledge complementarity on new product innovativeness in China. Organization Science, 22(1): 158-172.

Ferrary, M. 2011. Specialized organizations and ambidextrous clusters in the open innovation paradigm. European Management Journal, 29(3): 181-192.

Fornell, C., \& Larcker, F. 1981. Evaluating structural equation models with unobservable variables and measurement error. Journal of Marketing Research, 18(1): 39-50.

Fornell, C., \& Yi, Y. 1992. Assumptions of the two-step approach to latent variable modeling. Sociological Methods \& Research, 20(3): 291-320.

Garcia, R., \& Calantone, R. 2002. A critical look at technological innovation typology and innovativeness terminology: A literature review. Journal of Product Innovation Management, 19(2): 110-132.

Gassmann, O., \& Enkel, E. 2004. Towards a theory of open innovation: Three core process archetypes. In $R \& D$ management conference: $1-18$.

Grant, R. 1996. Toward a knowledge-based theory of the firm. Strategic management journal, 17(S2): 109-122.

Griffin, A. 1997. PDMA research on new product development practices: Updating trends and benchmarking best practices. Journal of Product Innovation Management, 14(6): 429-458.

Gronum, S., Verreynne, M. L., \& Kastelle, T. 2012. The role of networks in small and medium-sized enterprise innovation and firm performance. Journal of Small Business Management, 50(2): 257-282.

Hair, J., Tatham, R., Anderson, R., \& Black, W. 2013. Multivariate Data Analysis, 7th ed. Upper Saddle River, NJ:Prentice-Hall.

Harmancioglu, N. 2009. Portfolio of controls in outsourcing relationships for global new product development. Industrial Marketing Management, 38(4): 394-403.

Henard, D., \& Szymanski, D. 2001. Why some new products are more successful than others. Journal of Marketing Research, 38(3): 362-375.

Henderson, R., \& Clark, K. 1990. Architectural innovation: The reconfiguration of existing product technologies and the failure of established firms. Administrative Science Quarterly, 35(1): 9-30.

Hernández-Espallardo, M., Sánchez-Pérez, M., \& Segovia-López, C. 2011. Exploitation-and explorationbased innovations: The role of knowledge in inter-firm relationships with distributors. Technovation, 31(5): 203-215.

Ho, M. H. W., Ghauri, P. N., \& Larimo, J. A. 2018. Institutional distance and knowledge acquisition in international buyer-supplier relationships: The moderating role of trust. Asia Pacific Journal of Management, 35(2): 427-447.

Huizingh, E. 2011. Open innovation: State of art and future perspectives. Technovation, 31(1): 2-9.

Investopedia. 2016. Top 25 developed and developing countries, 28 September edition, Retrieved on 12 September 2018 from https://www.investopedia.com/updates/top-developing-countries/. Accessed 12 Sept 2018. 
Jarvenpaa, S. L., \& Wernick, A. 2011. Paradoxical tensions in open innovation networks. European Journal of Innovation Management, 14(4): 521-548.

Kafouros, M., Wang, C., Piperopoulos, P., \& Zhang, M. 2015. Academic collaborations and firm innovation performance in China: The role of region-specific institutions. Research Policy, 44(3): 803-817.

Keupp, M. M., Palmié, M., \& Gassmann, O. 2012. The strategic management of innovation: A systematic review and paths for future research. International Journal of Management Reviews, 14(4): 367-390.

Kohtamäki, M., Partanen, J., Parida, V., \& Wincent, J. 2013. Non-linear relationship between industrial service offering and sales growth: The moderating role of network capabilities. Industrial Marketing Management, 42(8): 1374-1385.

Lakemond, N., Bengtsson, L., Laursen, K., \& Tell, F. 2016. Match and manage: The use of knowledge matching and project management to integrate knowledge in collaborative inbound open innovation. Industrial and Corporate Change, 25(2): 333-352.

Laursen, K., \& Salter, A. 2006. Open for innovation: The role of openness in explaining innovation performance among U.K. manufacturing firms. Strategic Management Journal, 27(2): 131-150.

Lee, Y., \& Colarelli O'Connor, G. 2003. The impact of communication strategy on launching new products: The moderating role of product innovativeness. Journal of Product Innovation Management, 20(1): 4-21.

Li, J., Poppo, L., \& Zhou, K. 2010. Relational mechanisms, formal contracts, and local knowledge acquisition by international subsidiaries. Strategic Management Journal, 31(4): 349-370.

Li, X., Zheng, Y., \& Wang, C. 2016. Inter-firm collaboration in new product development in Chinese pharmaceutical companies. Asia Pacific Journal of Management, 33(1): 165-193.

Liang, Q., Li, X., Yang, X., Lin, D., \& Zheng, D. 2013. How does family involvement affect innovation in China? Asia Pacific Journal of Management, 30(3): 677-695.

Liu, F. H., Tsou, H. T., \& Chen, L. J. 2013. The impact of OEM supplier initiatives on buyer competence development: The moderating roles of collaborative relationship and competitive environment. Asia Pacific Journal of Management, 30(4): 1285-1303.

Liu, W., Yang, H., \& Zhang, G. 2012. Does family business excel in firm performance? An institution-based view. Asia Pacific Journal of Management, 29(4): 965-987.

Liu, Y., Chen, Y., \& Wang, L. 2017. Family business, innovation and organizational slack in Taiwan. Asia Pacific Journal of Management, 34(1): 193-213.

Li-Ying, J., Wang, Y., \& Ning, L. 2016. How do dynamic capabilities transform external technologies into firms' renewed technological resources?-a mediation model. Asia Pacific Journal of Management, 33(4): 1009-1036.

Macneil, I. 1980. The new social contract: An inquiry into modern contractual relations. Yale University Press.

Meyer, A., Tsui, A., \& Hinings, C. 1993. Configurational approaches to organizational analysis. Academy of Management Journal, 36(6): 1175-1195.

Milligan, G. W., \& Sokol, L. M. 1980. A two-stage clustering algorithm with robust recovery characteristics. Educational and Psychological Measurement, 40(3): 755-759.

Mohr, J., \& Sengupta, S. 2002. Managing the paradox of inter-firm learning: The role of governance mechanisms. Journal of Business \& Industrial Marketing, 17(4): 282-301.

Mudambi, S. M., \& Tallman, S. 2010. Make, buy or ally? Theoretical perspectives on knowledge process outsourcing through alliances. Journal of Management Studies, 47(8): 1434-1456.

Muthen, L., \& Muthén, B. 2010. Mplus user's guide, v. 6.1. Los Angeles, CA:Muthén \& Muthén.

Nasdaq. 2012.What is the difference between a developed, Emerging and Frontier Market? [online] 11 May 2012. Available from: http://www.nasdaq.com/article/what-is-the-difference-between-a-developedemerging-and-frontier-market-cm140649 [Accessed on 12 September 2018]

Nyaga, G. N., Whipple, J. M., \& Lynch, D. 2010. Examining supply chain relationships: Do buyer and supplier perspectives on collaborative relationships differ? Journal of operations management, 28(2): 101-114.

Pan, Y., Xu, Y. C., Wang, X., Zhang, C., Ling, H., \& Lin, J. 2015. Integrating social networking support for dyadic knowledge exchange: A study in a virtual community of practice. Information \& Management, 52(1): 61-70.

Parida, V., Westerberg, M., \& Frishammar, J. 2012. Inbound open innovation activities in high-tech SMEs: The impact on innovation performance. Journal of Small Business Management, 50(2): 283-309.

Park, N. K., Mezias, J. M., Lee, J., \& Han, J. H. 2014. Reverse knowledge diffusion: Competitive dynamics and the knowledge seeking behavior of Korean high-tech firms. Asia Pacific Journal of Management, 31(2): 355-375.

Podsakoff, P., MacKenzie, S., \& Podsakoff, N. 2012. Sources of method bias in social science research and recommendations on how to control it. Annual review of psychology, 63(1): 539-569. 
Punj, G., \& Stewart, D. W. 1983. Cluster analysis in marketing research: Review and suggestions for application. Journal of Marketing Research, 20(2): 134-148.

Rindfleisch, A., \& Moorman, C. 2001. The acquisition and utilization of information in new product alliances: A strength-of-ties perspective. Journal of marketing, 65(2): 1-18.

Ritala, P., Olander, H., Michailova, S., \& Husted, K. 2015. Knowledge sharing, knowledge leaking and relative innovation performance: An empirical study. Technovation, 35: 22-31.

Saebi, T., \& Foss, N. 2015. Business models for open innovation: Matching heterogeneous open innovation strategies with business model dimensions. European Management Journal, 33(3): 201-213.

Schleimer, S. C., \& Shulman, A. 2011. A comparison of new service versus new product development: Configurations of collaborative intensity as predictors of performance. Journal of Product Innovation Management, 28(4): 521-535.

Schumpeter, J. 1939. Business cycles: A theoretical, historical, and statistical analysis of the capitalist process, vol. 2. New York:McGraw-Hill.

Shiu, E., Hair, J. Bush, R., \& Ortinau, D. 2009. Marketing research European edition, McGraw-Hill Higher Education.

Simonin, B. L. 1999. Transfer of marketing know-how in international strategic alliances: An empirical investigation of the role and antecedents of knowledge ambiguity. Journal of International business studies, 30(3): 463-490.

Singh, J. 1990. A typology of consumer dissatisfaction response styles. Journal of Retailing, 66(1): 57-100.

Sisodiya, S., Johnson, J., \& Grégoire, Y. 2013. Inbound open innovation for enhanced performance: Enablers and opportunities. Industrial Marketing Management, 42(5): 836-849.

Srikanth, K., \& Puranam, P. 2011. Integrating distributed work: Comparing task design, communication, and tacit coordination mechanisms. Strategic Management Journal, 32(8): 849-875.

Staudenmayer, N., Tripsas, M., \& Tucci, C. 2005. Interfirm modularity and its implications for product development. Journal of Product Innovation Management, 22(4): 303-321.

Vaidyanathan, G., Devaraj, S., \& D'Arcy, J. 2012. Does security impact E-procurement performance? Testing a model of direct and moderated effects. Decision Sciences, 43(3): 437-458.

Van Burg, E., Berends, H., \& Van Raaij, E. M. 2014. Framing and interorganizational knowledge transfer: A process study of collaborative innovation in the aircraft industry. Journal of Management Studies, 51(3): 349-378.

Van de Vrande, V., De Jong, J. P., Vanhaverbeke, W., \& De Rochemont, M. 2009. Open innovation in SMEs: Trends, motives and management challenges. Technovation, 29(6-7): 423-437.

Wang, C. H., Chang, C. H., \& Shen, G. C. 2015. The effect of inbound open innovation on firm performance: Evidence from high-tech industry. Technological Forecasting and Social Change, 99: 222-230.

West, J., \& Bogers, M. 2014. Leveraging external sources of innovation: A review of research on open innovation. Journal of Product Innovation Management, 31(4): 814-831.

West, J., Salter, A., Vanhaverbeke, W., \& Chesbrough, H. 2014. Open innovation: The next decade. Research Policy, 43(5): 805-811.

Yang, H., Dess, G., \& Robins, J. 2018. Does entrepreneurial orientation always pay off? The role of resource mobilization within and across organizations. Asia Pacific Journal of Management, 1-27.

Zhou, K., \& Li, C. 2012. How knowledge affects radical innovation: Knowledge base, market knowledge acquisition, and internal knowledge sharing. Strategic Management Journal, 33(9): 1090-1102.

Publisher's note Springer Nature remains neutral with regard to jurisdictional claims in published maps and institutional affiliations.

Colin C.J. Cheng (PhD, University of Birmingham) is an associate professor at College of Business, National Taipei University in Taiwan. His research focus is in innovation. He has previously published in well-regarded journals, such as Journal of Product Innovation Management, Technovation, International Journal of Production Economics, and Journal of Cleaner Production.

Eric Shiu ( $\mathrm{PhD}$, University of Edinburgh) is a lecturer at the Department of Marketing, University of Birmingham in the UK. His main research area is in innovation. He has published in various renowned journals, such as Technovation, International Journal of Innovation Management, Journal of Business Research, and Transportation Research Policy and Practice. 